\title{
OBSERVASI KLINIK EFEK FORMULA JAMU DISPEPSIA TERHADAP FUNGSI HATI
}

\author{
Agus Triyono, PR Widhi Astana, Sunu Pamadyo T.I. \\ Balai Besar Penelitian dan Pengembangan Tanaman Obat dan Obat Tradisional \\ Tawangmangu, Jl. Lawu no 11 Tawangmangu Karanganyar Jawa Tengah \\ (agustriyono_21@yahoo.com)
}

\begin{abstract}
ABSTRAK
Dispepsia adalah sindrom yang mencakup satu atau lebih dari gejala perasaan perut penuh setelah makan, cepat kenyang atau rasa terbakar di ulu hati, yang berlangsung sedikitnya dalam 3 bulan terakhir. Dispepsia sering ditemukan dalam praktik dokter sehari-hari. Telah dilakukan penelitian efek formula jamu dispepsia terhadap fungsi hati (SGOT dan SGPT). Uji klinik dilakukan dengan desain penelitian pre-post test desaign pada 69 subjek penelitian yang memenuhi kriteria inklusi dan eksklusi. Subjek penelitian minum formula jamu dispepsia tiga kali sehari selama delapan minggu dengan kontrol seminggu sekali. Setiap kontrol dilakukan observasi kinik kemungkinan efek samping dan gambaran fisik diagnostik. Subjek penelitian dilakukan pemeriksaan SGOT dan SGPT setiap empat minggu. Hasil anamnesis dan pemeriksaan klinik selama perlakuan dan sesudah perlakuan tidak ditemukan efek samping yang bermakna. Hasil uji t berpasangan sebelum perlakuan dibanding sesudah perlakuan 28 hari untuk kadar SGOT, nilai p 0.434 (>0.05) dan kadar SGPT nilai p 0.689 (>0.05). Hasil uji t berpasangan sebelum perlakuan dibanding sesudah perlakuan 56 hari untuk kadar SGOT nilai p 0.120 (>0.05) dan kadar SGPT nilai p 0.533 (>0.05). Jadi disimpulkan bahwa penggunaan formula jamu dispepsia selama 56 hari tidak ditemukan efek samping yang bermakna, dan tidak mengganggu fungsi hati.
\end{abstract}

Kata kunci: fungsi hati, formula jamu dispepsia

\begin{abstract}
Dyspepsia is a syndrome that includes one or more of the symptoms of the stomach feeling full after eating, satiety or burning sensation in the pit of the stomach, which takes place at least in the last 3 months. Dyspepsia is often found in medical practice. Has conducted research the effect of dyspepsia herbs formula to the liver functions (SGOT and SGPT). Safety of clinical trials were conducted by the study of pre - post design research. It was involving 69 subjects who have met the inclusion and exclusion criteria. Subject drink the dyspepsia herb formula three times a day for eight weeks, then controlled it once a week. Each control conducted clinical observation the possibility of side effects and performed a physical examination diagnostic. Research subjects examined liver function (SGOT and SGPT) every four weeks. The results of anamsesis and physical examination on the subject during treatment and after treatment was not found significant side effects. Results of analysis of paired test showed, there was no significant difference $(t<0,05)$ levels of SGOT and SGPT before treatment and after giving dyspepsia herbs formula in day $28^{\text {th }}$ and $56^{\text {th }}$.
\end{abstract}


Giving dyspepsia herbs formula for 56 days on the subject of the study found no symptoms of serious side effects, as well as not to disturb liver function.

Keywords: liver function, dyspepsia herbs formula

\section{PENDAHULUAN}

Menurut Kriteria Roma III terbaru dispepsia didefinisikan sebagai sindrom yang mencakup satu atau lebih dari gejala-gejala perasaan perut penuh setelah makan, cepat kenyang, atau rasa terbakar di ulu hati, yang berlangsung sedikitnya dalam 3 bulan terakhir, dengan awal mula gejala sedikitnya timbul 6 bulan sebelum diagnosis. $^{(1)}$

Dispepsia sering dijumpai dalam praktik klinis sehari-hari. Dispepsia berada pada peringkat ke-10 dengan proporsi $15 \%$ untuk kategori penyakit pada pasien rawat jalan dan menempati urutan ke-15 dengan proporsi 19\% pada kategori penyakit rawat inap di seluruh Rumah Sakit di Indonesia pada tahun 2005. (2)

Pada tahun 2011 dispepsia menempati peringkat ke 6 untuk kunjungan rawat jalan dan rawat inap sedangkan pada tahun 2012 menempati peringkat ke 5 untuk seluruh kunjungan rawat jalan dan rawat inap pada seluruh Rumah Sakit di Indonesia. (2)

Di berbagai sarana pelayanan kesehatan prevalensi dispepsia cenderung meningkat setiap tahun. Dispepsia memang bukanlah suatu penyakit yang mengancam jiwa, namun nyeri yang dapat datang sewaktu-waktu terasa sangat mengganggu penderitanya. Penyakit ini juga bukan merupakan suatu penyakit yang dapat sembuh sendiri (self limited disease), sehingga upaya pengobatan, mengurangi frekuensi dan intensitas serangan dispepsia akut sangat diperlukan. Pengobatan farmakologis untuk pasien dispepsia fungsional belum begitu memuaskan. ${ }^{(3)}$

Patofisiologi dyspepsia fungsional telah banyak diteliti dalam dua decade terakhir, tetapi masih belum ada pathogenesis yang pasti. Beberapa mekanisme dicurigai berperan terhadap dyspepsia fungsional,yaitu : factor fisiologis, genetic, lingkungan, psikologis, dan interaksi otak usus (brain gut interaction) ${ }^{(4)}$

Berdasarkan

Permenkes No.003/MENKES/PER/I/2010 tentang Saintifikasi Jamu disebutkan bahwa saintifikasi jamu adalah pembuktian ilmiah khasiat dan keamanan jamu. Saintifikasi jamu dilakukan melalui observasi klinik yaitu penelitian berbasis pelayanan kesehatan yang merupakan terobosan Kementerian Kesehatan dalam upaya memberikan dukungan ilmiah (evidence based) terhadap jamu untuk dapat dimanfaatkan dalam pelayanan kesehatan formal. ${ }^{(5)}$

Kecenderungan back to nature masyarakat Indonesia maupun manca negara saat ini, merupakan suatu peluang yang cukup besar bagi obat bahan alam untuk menggantikan obat modern walaupun belum secara penuh. Peluang pasar masih cukup luas untuk pemenuhan kebutuhan dalam negeri maupun ekspor. Kebutuhan dalam negeri meningkat setiap tahunnya sebagaimana tercermin dari pertumbuhan jumlah Industri Obat Tradisional (IOT) dan Industri Kecil Obat Tradisional (IKOT) di Indonesia ${ }^{(6)}$

Ada beberapa tanaman berdasarkan uji praklinis dan observasi klinis berkhasiat menurunkan gejala dyspepsia yaitu : Kunyit (Curcuma domestica), Jahe (Zingiber officinale), Jinten hitam (Nigella sativa) dan Sembung (Blumea balsamifera)

Hasil uji toksisitas akut dan sub kronis menggunakan hewan coba ramuan keempat tanaman tersebut menunjukkan tidak ada perbedaan dengan kontrol negatif/tanpa perlakuan (tidak bersifat 
toksik). Pada hewan coba air rebusan ramuan diatas juga didapatkan penurunan skor ulkus gaster (bersifat gastroprotektif). Penghyunaan Air rebusan ramuan pada 33 pasien memberikan respon yang lebih baik jika digunakan secara ramuan (gabungan) dibandingkan dengan digunakan sendirisendiri, yaitu mengurangi frekuensi dan intensitas nyeri. $^{(7)}$

Formula jamu yang terbukti berkhasiat dapat digunakan dalam masyarakat dan pelayanan kesehatan formal dengan sarat tidak menganggu fungsi hati dan fungsi ginjal. Sehubungan dengan hal diatas, telah dilakukan penelitian uji klinik pengaruh formula jamu dispepsia terhadap fungsi hati sebagain dasar pemanfaatan di masyarakat dan pelayanan kesehatan formal.

\section{METODE PENELITIAN}

\section{BAHAN}

Bahan baku yang digunakan sebagai simplisia diambil dari daerah tawangmangu, determinasi dan pengelolaan simplisia dilakukan di B2P2TO2T Tawangmangu. Bahan baku simplisia terlebih dahulu melalui proses pemilihan bahan secara fisik, kemudian diuji kromatografi lapis tipis dan kontrol kualitas. Pembuatan bahan dan kontrol kualitas dilakukan oleh tim Quality Control B2P2TO2T Tawangmangu.

Bahan dicuci dengan air yang mengalir untuk menghilangkan kotoran yang menempel, kemudian dianginanginkan dilanjutkan pengeringan di dalam oven suhu $50{ }^{0} \mathrm{C}$ selama 7 jam. Simplisia kering dilakukan pengemasan dengan dosis rimpang kunyit 15 gram, rimpang jahe 15 gram, jinten hitam 2 gram, dan herba sembung 15 gram.

\section{PROSEDUR}

Uji klinik dilakukan dengan rancangan penelitian pre-post test desaign. Uji klinik dilakukan di Rumah Riset Jamu Tawangmangu. Penelitian melibatkan 69 subjek penelitian yang telah memenuhi kriteria inklusi dan eksklusi. Kriteria inklusi adalah : Usia 18 - 45 tahun, laki-laki atau perempuan, subyek dengan dispepsia kronis sesuai dengan kriteria Roma III, bersedia mengikuti penelitian/jadwal follow up dengan menandatangani informed consent. Kriteria eksklusi adalah : perempuan hamil atau menyusui (berdasarkan pengakuan), subjek dengan komplikasi penyakit berat (misal kanker stadiumlanjut/ terminal dll).

Subjek penelitian yang telah menandatangani informed consent, pada H0 dilakukan anamnesis identitas subjek, riwayat penyakit, gejala klinis, pemeriksaan fisik diagnostik, dan pemeriksaan laboratorium fungsi hati (SGOT dan SGPT). Subjek penelitian diberi formula jamu dalam jumlah untuk penggunaan selama satu minggu, kemudian kontrol seminggu sekali sampai delapan minggu, setiap kontrol diberikan bahan uji formula jamu untuk penggunaan selama satu minggu. Mulai hari pertama subjek penelitian merebus dan minum jamu ( satu kemasan direbus dengan 5 gelas $(1000 \mathrm{cc})$ air sampai mendidih sehingga air tinggal 3 gelas diminum pagi, siang dan sore satu gelas satu gelas), satu kemasan untuk satu hari, hari berikutnya merebus kemasan yang baru. Subjek penelitian kontrol setiap seminggu sekali untuk dilakukan anamnesis kemungkinan efek samping dan dilakukan pemeriksaan fisik diagnostik. Dilakukan pemeriksaan laboratorium fungsi hati (SGOT dan SGPT) setiap empat minggu sekali.

Penelitian ini telah mendapatkan ethical clearance dari Komisi Etik Badan Penelitian dan Pengembangan Kesehatan Kementerian Kesehatan RI di Jakarta. 
HASIL DAN PEMBAHASAN

Telah dilakukan penelitian uji klinik efek formula jamu dispepsia di Rumah Riset Jamu Tawangmangu. Subjek penelitian berjumlah 69 orang yang memenuhi kriteria inklusi dan eksklusi telah mengikuti penelitian ini.
Hasil anamnesis dan pemeriksaan fisik pada subjek penelitian selama perlakuan dan sesudah perlakuan tidak ditemukan efek samping yang bermakna.

Rerata nilai SGOT dan SGPT subjek penelitian sebelum dan sesudah perlakuan ditampilkan pada Tabel-1.

Tabel-1.Rerata nilai SGOT dan SGPT subjek penelitian sebelum perlakuan (H0) dan sesudah perlakuan (H28 dan $\mathrm{H} 56)$

\begin{tabular}{lrrr}
\hline $\begin{array}{l}\text { Parameter } \\
\text { Fungsi Hati }\end{array}$ & & & \\
& H0 & H28 & H56 \\
\hline SGOT (U/L) & 26.71 & 24.23 & 22.71 \\
SGPT (U/L) & 28.47 & 28.27 & 27.06 \\
\hline
\end{tabular}

Untuk mengetahui pengaruh pemberian formula jamu dispepsia terhadap fungsi hati, dilakukan analisis perbedaan kadar SGOT dan SGPT sebelum dan setelah pemberian jamu dengan uji t berpasangan. Hasil analisis tersebut ditampilkan pada tabel-2. dan tabel-3.
Pada Tabel-2 menunjukkan bahwa tidak terdapat perbedaan yang bermakna kadar SGOT $(\mathrm{p}=0.434$ $(\mathrm{p}>0,05))$ dan SGPT $(\mathrm{p}=0.689(\mathrm{p}>0,05))$ sebelum perlakuan $(\mathrm{HO})$ dan sesudah pemberian formula jamu dispepsia hari ke-28 (H28).

Tabel-2. Analisis Perbedaan Kadar SGOT dan SGPT sebelum perlakuan (H0) dan sesudah perlakuan $(\mathrm{H} 28)$

\begin{tabular}{clcccc}
\hline \multirow{2}{*}{ Fungsi hati } & \multicolumn{2}{l}{ Sebelum perlakuan (H0) } & \multicolumn{2}{c}{ Sesudah perlakuan $(\mathrm{H} 28)$} & \multirow{2}{*}{ p } \\
\cline { 2 - 5 } & mean & SD & mean & SD & 0.434 \\
\hline SGOT & 26.71 & 7.86 & 24.23 & 6.55 & 0.689 \\
SGPT & 28.47 & 7.25 & 28.27 & 6.43 & \\
\hline
\end{tabular}

Tabel-3. Analisis Perbedaan Kadar SGOT dan SGPT sebelum perlakuan (H0) dan sesudah perlakuan (H56)

\begin{tabular}{clcccc}
\hline \multirow{2}{*}{ Fungsi hati } & \multicolumn{2}{l}{ Sebelum perlakuan $(\mathrm{H} 0)$} & \multicolumn{2}{c}{ Sesudah perlakuan (H56) } & \multirow{2}{*}{$\mathrm{p}$} \\
\cline { 2 - 5 } & mean & SD & mean & SD & \\
\hline SGOT & 26.71 & 7.86 & 22.71 & 6.14 & 0.120 \\
SGPT & 28.47 & 7.25 & 27.06 & 6.40 & 0.533 \\
\hline
\end{tabular}


Tabel-3. menunjukkan bahwa tidak terdapat perbedaan yang bermakna kadar SGOT $(\mathrm{p}=0.120(\mathrm{p}>0,05))$ dan SGPT $(\mathrm{p}=0.533(>0,05))$ sebelum perlakuan (H0) dan sesudah pemberian formula jamu dispepsia hari ke-56 (H56). Enzim SGOT (serum glutamic oxaloacetic transminase) dan SGPT (serum glutamic pyruvic transaminase) merupakan serum transaminase yang peka pada kerusakan sel-sel hati. Peningkatan $2 \mathrm{x}$ atau lebih dari harga normal enzim SGOT dan SGPT merupakan tanda pasti adanya gangguan sel hati. Kenaikan enzim-enzim tersebut bisa disebabkan kerusakan sel-sel hati oleh ramuan jamu atau obat-obatan yang toksik terhadap sel sel hati (hepatotoksik). Rerata hasil pemeriksaan SGOT dan SGPT sebelum perlakuan dan setelah perlakuan hari ke28 dan hari ke-56 masih dalam batas normal (nilai normal SGOT 3 - $45 \mathrm{u} / \mathrm{L}$, SGPT $2-35 \mathrm{u} / \mathrm{L}$ ). Hasil analisis diatas didapatkan nilai SGOT dan SGPT sebelum dan sesudah minum ramuan jamu tidak berbeda bermakna, berarti penggunaan ramuan jamu dyspepsia 56 hari tidak mengganggu fungsi hati. ${ }^{9}$

\section{KESIMPULAN}

Penggunaan ramuan jamu dispepsia selama 56 hari secara klinis tidak ditemukan efek samping yang bermakna dan tidak mengganggu fungsi hati.

\section{ACKNOWLEDGE}

Peneliti mengucapkan terimakasih dan penghargaan kepada Kepala Badan Litbangkes RI, Tim Komnas Saintifikasi Jamu, dan Kepala Balai Besar Tanaman Obat dan Obat Tradisional beserta jajarannya, yang telah memberikan kesempatan dan melancarkan jalannya kegiatan penelitian sampai dengan selesai. Peneliti juga mengucapkan terima kasih kepada subjek penelitian, yang sudah berperan secara penuh dalam penelitian.

\section{DAFTAR PUSTAKA}

1. Chang L, 2006. The Rome Criteria for the Functional GI disorders. Medscape. Available from: http://www.medscape.com/viewarticl e/533460

2. Djojoningrat D, 2001. Dispepsia Fungsional. In: Suyono, S.H., Buku Ajar: Ilmu Penyakit Dalam. $3^{\text {rd }}$ ed. Jakarta: Balai Penerbit FKUI, 153 155

3. Horrison Principles of Internal Medicine, 2001.15 th edition, Mc Grow Hill, New York

4. Tcokroprawiro Askandar, 2015. Buku Ajar Ilmu Penyakit Dal;am, Edisi-2. Surabaya. FK Universitas Airlangga.

5. Peraturan Menteri Kesehatan Republik Indonesia. Nomor: 003/MENKES/PER /I/ 2010 tentang Saintifikasi Jamu dalam Penelitian Berbasis Pelayanan Kesehatan. Jakarta. 2010.

6. Himpunan Seminat Apoteker, Industri Obat Tradisional, Daftar Obat Alam, Edisi III, 2008

7. Peraturan Menteri Kesehatan RI Nomor 1109/Menkes/Per/IX/2007 tentang Penyelenggaraan Pengobatan Komplementer Alternatif di Fasilitas Pelayanan Kesehatan. Jakarta. 2007.

8. Badan Litbang Kesehatan. Pedoman Observasi Klinik Obat Tradisional Berbasis Masyarakat. Draft. 2009

9. Mc.Gilvery, R.W.and Golstein, G.W.,1996, Biokimia Suatu Pendekatan Fungsional, Edisi ketiga, Airlangga University Press, Jakarta 